ENERGY DREAMS 



\section{ENERGY DREAMS}

OF ACT UALITY

MICHAEL MARDER

Columbia University Press

New York 


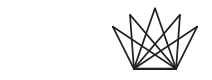

Columbia University Press

Publishers Since 1893

New York Chichester, West Sussex

cup.columbia.edu

Copyright (C) 2017 Columbia University Press

All rights reserved

\section{Library of Congress Cataloging-in-Publication Data}

Names: Marder, Michael, 1980- author.

Title: Energy dreams : of actuality / Michael Marder.

Description: New York : Columbia University Press, 2017. |

Includes bibliographical references and index.

Identifiers: LCCN 2016035594| ISBN 9780231180580 (cloth : alk. paper) |

ISBN 9780231180597 (pbk. : alk. paper)| ISBN 9780231542838 (e-book)

Subjects: LCSH: Psychic energy (Psychoanalysis) | Power (Social sciences) |

Political science-Philosophy.

Classification: LCC BF175.5.P72 M37 2017 | DDC 118-dc23

LC record available at https://lccn.loc.gov/2016035594

Columbia University Press books are printed on permanent and durable acid-free paper.

Printed in the United States of America

Jacket design: Milenda Nan Ok Lee 
FOR PATRÍCIA,

WITH THE ENERGY OF LOVE

"L'AMOR CHE MOVE IL SOLE

E L'ALTRE STELLE”

-DANTE, PARADISO XXXIII, 145

e 
